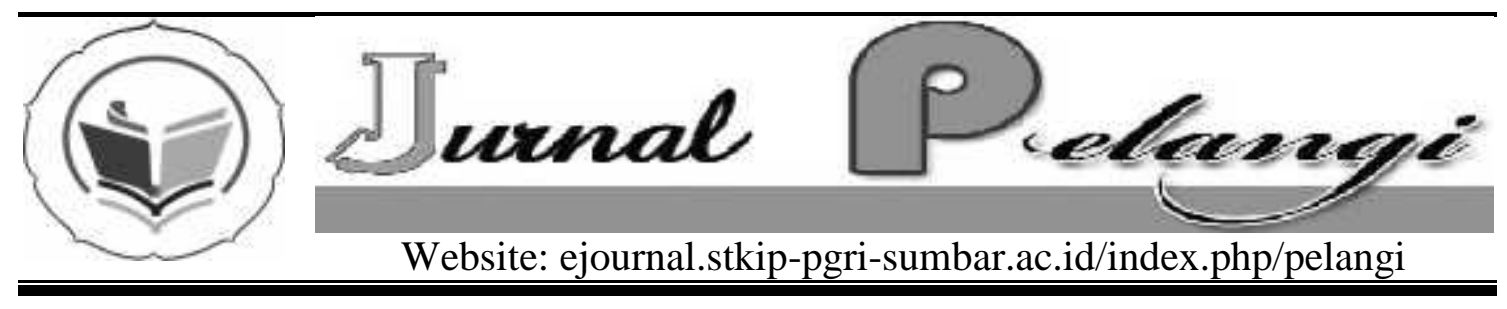

\title{
PEMBERDAYAAN MASYARAKAT MELALUI PKPEK TERHADAP PENGRAJIN PEYEK DI DUSUN PELEMADU
}

\author{
Rinel Fitlayeni \\ STKIP PGRI Sumatera Barat \\ rin31_inzaghi@yahoo.co.id
}

\begin{tabular}{l}
\hline INFO ARTIKEL \\
\hline Diterima : \\
Disetujui : \\
\hline Kata Kunci: \\
\hline Pemberdayaan, \\
Masyarakat \\
\hline
\end{tabular}

Keywords:

\section{Empowerment, Community}

\begin{abstract}
Abstrak
Keberadaan PKPEK (Masyarakat Penelitian dan Pengembangan Ekonomi Masyarakat) sebagai salah satu LSM yang bertujuan untuk memberdayakan masyarakat untuk meningkatkan pendapatan masyarakat dari Pelemadu setelah gempa besar terjadi pada tahun 2006. Gempa ini menyebabkan banyak korban baik secara materil maupun non materil. Setelah masuknya PKPEK ini, LSM ini memberikan peningkatan yang signifikan untuk pendapatan masyarakat, khususnya perajin penyok.Keberadaan PKPEK dimulai dengan perubahan dalam pandangan dilihat dari aspek perubahan dalam badan usaha yang menyediakan infrastruktur yang diperlukan oleh masyarakat sebagai aset, tenaga kerja dan motivasi. Sementara itu, kendala yang dihadapi selama proses mentoring, antara lain: a) modal bahan baku terutama, b) alat-alat produksi, c) pasar dan d) harga.
\end{abstract}

\footnotetext{
Abstract

Existence PKPEK (Society for Research and Development of Community Economy) as one NGO aims to empower communities to improve people's income Pelemadu after the massive earthquake that occurred in 2006. The earthquake caused many casualties both material and non materti. Upon entry there PKPEK a significant increase of the income of the people, especially artisans dent.

PKPEK existence begins with a change in the views seen from the aspect of change in the business entity, to provide infrastructure needed by the community as an asset, manpower and motivation. While the obstacles faced during the process of mentoring, among others: a) capital mainly raw materials, b) the means of production, $c$ ) market and d) price.
} 


\section{PENDAHULUAN}

Peristiwa gempa bumi yang terjadi di Daerah Istimewa Yogyakarta pada tahun 2006 merupakan bencana yang cukup besar karena banyak korban yang berjatuhan baik meninggal maupun luka-luka. Selain memakan korban nyawa, juga terdapat korban materi yaitu hilangnya kekayaan dan hancurnya tempat tinggal.

Berangkat dari pengalaman tsunami di Aceh dan Nias, terdapat 7 hal yang menjadi rusak yaitu, (a) psikologis diri (jiwa) masyarakat, (b) pemerintah: kemampuan dan sistem kerjanya, (c) infrastruktur : transportasi dan komunikasi rusak, (d). sarana dan prasarana ekonomi, (e) sistem perbankan dan produksi belum normal, (f) citra: rusaknya citra daerah sebagai kawasan yang layak untuk berbisnis dan berwisata, (g) manajemen pengelolaan kepulihan ekonomi (recovery management) daerah belum dapat bekerja efektif dan efisien

Salah satu daerah yang cukup parah terkena gempa adalah Dusun Pelemadu, Kecamatan Imogiri, salah satu daerah yang terkena dampak gempa cukup parah. Akibatnya masyarakat harus menanggung beban kehidupan yang tidak dapat dipastikan kapan berakhirnya dan rawannya kantongkantong kemiskinan. Imogiri memiliki jumlah kepala keluarga (KK) sebanyak 16.818 dengan jumlah KK miskin mencapai 6.521 (38,77\%), jumlah ini menempatkan Kecamatan Imogiri sebagai kecamatan yang memiliki KK miskin terbanyak, yaitu pada posisi 17 dari 17 kecamatan yang dimiliki Kabupaten Bantul (http://gis.deptan.go.id/website/sipetin/k abupaten/BANTUL5.htm)
Ada dua kondisi yang menyebabkan masyarakat menjadi miskin yaitu kemiskinan alamiah dan kemiskinan buatan. Kemiskinan alamiah terjadi akibat sumber daya alam yang terbatas, penggunaan teknologi yang rendah dan bencana alam. Sedangkan kemiskinan buatan terjadi karena lembaga yang ada dalam masyarakat, membuat sebagian anggota masyarakat yang lain tidak mampu menguasai sarana ekonomi dan berbagai fasilitas lain yang tersedia, sehingga mereka tetap miskin. Dusun Pelemadu termasuk kemiskinan yang disebabkan kondisi alamiah. Kondisi seperti itu tentu saja membutuhkan bantuan dari semua pihak terutama pemerintah sehingga masyarakat bisa segera memulihkan kondisi ekonomi rumah tangga mereka.

Sebelum terjadinya gempa, masyarakat disana telah memiliki industri rumah tangga sendiri yang cukup berkembang yaitu peyek. Jika dilihat pada tahun 1992 hanya ada sekitar 2 sampai 3 orang yang pengrajin peyek. Tapi sekitar tahun 2002 ada sekitar 41 kelompok pengrajin peyek disana. Gampa yang terjadi tentu memporak porandakan industri peyek tersebut.

Untuk membangkitkan dan mengembangkan kembali usaha tersebut bukanlah jalan yang mudah karena menyangkut semua aspek terutama masalah modal, bahan baku, pemasaran bahkan psikis masyarakat (disebabkan trauma). Pasca gempa, pemerintah melalui Perindag (Departemen Industri) telah memberikan bantuan kepada pengrajin peyek untuk masing-masing 
40 pengrajin dana sekitar Rp. 1.000.000,-/ orang.

Dana yang disalurkan hanya bisa membantu untuk sementera karena pemerintah tidak memberikan pengarahan bagaimana cara mengembangkan kembali usaha mereka. Setelah masuknya PKPEK (Perkumpulan untuk Kajian dan Pengembangan Ekonomi Kerakyatan) melakukan pendampingan / pemberdayaan terjadi perubahan signifikan terutama peningkatan pendapatan mereka dan menekan angka pengangguran. Hal ini disebabkan kerajinan peyek ini banyak menyerap tenaga kerja.

Kehadiran PKPEK sendiri pasca gempa, merupakan NGO yang bekerjasama antara Daerah Istimewa Jogyakarta dengan dengan Australia. Awalnya semua pengrajin mendapat bantuan secara hibah tapi berkala, untuk 2 dusun masing-masing mendapat $\mathrm{Rp}$. 60.000.000,. Wujud bantuan berupa barang yang bisa berkembang dan dikelola untuk penyediaan bahan baku. Jika dibandingkan sebelum terjadinya gempa, omset yang didapatkan pengrajin peyek setiap hari sekitar Rp. 2.000.000,- sekarang omset yang didapatkan masyarakat setiap hari sekitar Rp. 120.000.000, -

Dari uraian diatas, yang menjadi pertanyaan adalah bagaimana bentuk program PKPEK dan apa kendalakendala yang dihadapi oleh PKPEK sebagai salah satu pendamping untuk meningkatkan pendapatan masyarakat Dusun Palemadu, Kecamatan Imogiri.

\section{METODE PENELITIAN}

Pada umumnya mereka merupakan sebuah asosiasi sukarela yang dapat didefenisikan sebagai sekumpulan orang yang secara sukarela telah mengorganisasikan dirinya sendiri dalam mengejar tujuan-tujuan tertentu. Namun, karena posisinya yang relatif bebas dari kontrol birokrasi pemerintah, aosiasi-asosiasi sukarela ini penting dalam membantu pembaharuan pelayanan-pelayanan sosial sehingga dapat menopang pluraisme dan pemberdayaan masyarakat.

Pemberdayaan merupakan upaya mentransformasikan kesadaran masyarakat, sehingga masyarakat mau dan mampu mengambil bagian secara aktif untuk mendorong terjadinya perubahan. Pemberdayaan harus didasarkan pada prinsip keberpihakan kepada masyarakat marjinal, karena mereka berada dilapisan sosial paling bawah, sehingga memiliki posisi yang mampu memecahkan masalah untuk merubah posisi mereka.

Dengan demikian pemberdayaan tidak semata mata diarahkan kepada perbaikan kualitas hidup jangka pendek baik dalam konteks ekonomi (peningkatan kesejahteraan ekonomi) maupun sosial (pendidikan, kesehatan dil) tetapi secara strategi harus mengarah kepada proses untuk mendapatkan transformasi tatanan kehidupan jangka panjang.

Pemberdayaan masyarakat harus dapat menjawab kebutuhan praktis dan strategis (kebutuhan jangka pendek dan jangka panjang). Kenyataanya pemberdayaan masyarakat tidak dilepaskan dari keberadaaan orgnaisasi non pemerintah (ornop) atau NGO. Biasanya peran yang dilakukan NGO terhadap pemberdayaan rakyat dilakukan melalui tiga pendekatan yaitu pendekatan kemanusian (membantu 
secara sukarela kelompok masyarakat yang membutuhkan bantuan karena terkena musibah atau kurang beruntung), pendekatan pengembangan masyarakat (bertujuan mengembangkan, kemamandirian dan menswadayakan masyarakat), serta pendekatan pemberdayaan rakyat yang bertujuan memperkuat posisi tawar menawar masyarakat lapisan bawah terhadap kekuatan-kekuatan penekanan di segala bidang dan sektor kehidupan.

Begitu juga dengan yang terjadi di Dusun Pelemadu, Kecamatan Imogiri pasca gempa, pemberdayaan yang dilakukan disana tidak terlepas dari peran NGO (PKPEK) terutama bagi pengrajin peyek yang sekarang terkenal dengan sentral peyek.

\section{HASIL DAN PEMBAHASAN Bentuk Program PKPEK}

PKPEK merupakan salah satu NGO yang bersifat pembangunan partisipatif dengan konsep memberdayakan masyarakat. Artinya melibatkan masyarakat itu lebih maju dan dan mandiri dalam meningkatkan kehidupan baik sosial maupun ekonomi. Posisi PKPEK sebagai fasilitator dari apa yang direncanakan masyraakat dan mendukung penuh baik dari segi pemikiran maupun modal. PKPEK merupakan kerjasama antara daerah Yogyakarta dengan Australia yang terealisasi sekitar tahun 2007 pasca gempa.

Pelaksanaan kegiatan pemberdayaan diawali dengan membangun kepercayaan masyarakat melalui silaturahmi. Setelah mendapat kepercayaan dari beberapa orang maka mereka mulai berkumpul di balai pertemuan dusun untuk membicarakan kegiatan yang akan dilakukan. Pertemuan sesama anggota pengrajin peyek diagendakan menjadi rutinitas setiap dua minggu. Agenda ini membicarakan masalah / kendala yang dihadapi oleh anggota serta perkembangan pasar. Artinya PKPEK mencoba memberikan pemahaman dan pengetahuan mengenai kegiatan yang harus dilakukan oleh pengrajin peyek untuk meningkatkan pendapatan ekonomi mereka masyarakat pasca gempa.

Menurut Michael Foucault bahwa pengetahuan dan kekuasaan saling berkaitan. Dengan geneologi kekuasaan, Foucault membahas bagaimana orang mengatur diri sendiri dan orang lain melalui produksi pengetahuan. Diantaranya, ia melihat pengetahuan menghasilkan kekuasaan dengan mengangkat orang menjadi subyek dan kemudian memerintah subyek dengan pengetahuan. Kekuasaan itu tidak hanya menyebar dalam agen tapi juga dalam network atau wacana. Hal inilah yang dilakukan oleh PKPEK bahwa pengetahuan tersebut tidak hanya menyebar dalam anggota kelompok tapi juga luar kelompok dengan wacana untuk bahwa dengan membuat peyek bisa meningkatkan penghasilan. Sehingga banyak orang yang tertarik untuk membuat peyek dan bertani. Misalnya, orang yang dulunya sales untuk memasarkan peyek sekarang sudah bisa mengembangkan usaha peyek sendiri.

Pada tahap awal kegiatan PKPEK memberikan bantuan kepada semua pengrajin dengan cara bertahap untuk 2 dusun masing-masing menerima Rp. Rp. 60.000.000,- . Bantuan berbentuk batang yang bisa berkembang dan bisa dikelola 
untuk menyediakan bahan baku. Sampai sekarang keberadaannya PKPEK sudah membantu untuk bahan baku lebih dari Rp. 100.000.000,- .

Pada dasarnya pengrajin peyek telah ada sejak tahun 1992 dengan jumlah lebih kurang 3 orang. Pada tahun 2002 pengrajin bertambah menjadi 41 orang. Akibat gempa 2006 perekonomian masyarakat disana hancur karena pengrajin bukan hanya kehilangan anggota keluarga tapi juga tempat tinggal yang merupakan tempat usaha mereka.

Seperti yang diungkapkan oleh Pak Tri, salah seorang pendamping PKPEK, bahwa gempa yang terjadi telah melumpuhkan kegiatan pengrajin karena hampir $100 \%$ rumah disini rata dengan tanah. Kegiatan PKPEK diawali dengan merencanakan untuk melakukan perubahan yang berhubungan dengan ekonomi kerakyatan. Perubahan tersebut terutama dilihat dari aspek perubahan entitas usaha.

Pada aspek ini dalam bentuk sarana dan prasarana yang diusahakan untuk membantu pengrajin peyek antara lain :

a. Asset (modal usaha), karena gempa yang terjadi bukan saja menelan banyak korban nyawa tapi juga juga korban materi

b. Tenaga kerja, akibat bencana yang terjadi banyak masyarakat yang bertahan tapi pindah profesi dari bertani kacang tanah ke sektor lain. Salah satunya menjadi pengrajin peyek, profesi ini mulai ditekuni karna bahan baku mudah didapat, peralatan yang tidak terlalu berat serta mudah untuk membuatnya.

c. motivasi usaha para pelaku, maksudnya perlu ada motivasi bagi masyarakat untuk bangkit kembali dan mengembangkan kembali usaha mereka.

\section{Hambatan Yang Dihadapi PKPEK}

$\begin{array}{ccr}\quad \text { Proses } & \text { pendampingan } & \text { yang } \\ \text { dilakukan } & \text { PKPEK } & \text { untuk } \\ \text { memberdayakan } & \text { masyarakat } & \text { yang }\end{array}$ bertujuan untuk meningkatkan pendapatan masyarakat bukannya tanpa hambatan dan masalah. Adapun masalah yang dihadapi antara lain :

a. Modal (khusus bahan baku) seperti kacang tanah, Kecamatan Imogiri merupakan sentral kacang tanah. Saat ini produksi kacang tanah dimanfaatkan untuk bahan baku emergency. Akibatnya bahan baku ini didatangkan dari luar daerah Yogyakarta seperti Negara India, begitu juga dengan bahan baku lain yang didatangkan dari luar.

b. Sarana produksi, terutama tempat usaha mereka yang terkena gempa cukup parah. Akibatnya susah untuk mencari tempat produksi diantara reruntuhan rumah.

c. Pasar, terdapat 3 pasar di daerah Bantul yang mengalami kerusakan cukup serius. Akibatnya akses pengrajin peyek terbatas dan tidak terorganisir dengan baik untuk mendapatkan dan menjual hasil produksi.

d. Harga cendrung tidak stabil karna harga ditentukan oleh pedagang lokal. Hal ini disebabkan pengrajin di dukung oleh "tengkulak"

Berdasarkan hambatan yang dihadapi oleh PKPEK untuk kegiatan pemberdayaan masyarakat di Dusun Pelemadu, Kecamatan Imogiri, maka dirumuskan beberapa program yaitu :

1. Latihan motivasi kerja, salah satu dampak yang paling besar ketika 
terjadi bencana adalah hilangnya mata pencarian masyarakat. Sehubungan dengan hal tersebut bagi masyarakat di suatu wilayah yang mata pencariannya tergantung pada lahan biasanya lebih rentan dibandingkan wilayah yang tidak tergantung pada lahan. Begitu juga dengan Dusun Pelemadu yang mayoritas mata pencarian penduduk bertani kacang tanah sebelum terjadi gempa. Lahan pertanian sangat produktif, dalam setahun masyarakat bisa panen $3 x$, hal ini juga didukung oleh irigasi yang bagus.

2. Perbaikan sarana produksi (produksi masing-masing kelompok)

3. Stimulant bahan baku, pengelolaan melalui warung kelompok, karena selama ini masyarakat disini disuport oleh tengkulak. Misal, jika harga Rp.10.000 jika dipakai seminggu lagi Rp.10.500 maka yang dipakai harga terakhir

4. Pendampingan pemasaran keluar daerah, bukan sekedar meletakkan di supermarket. Untuk sekarang ini di Yogyakarta sudah hampir semua supermarket sudah meletakkam peyek disana. Misal untuk Mirota untuk satu seminggu ditaruh disana sekitar 100 bungkus.

5. Memetakan untuk setiap pengrajin peyek punya pasar masing-masing. Apabila ada suatu daerah yang meminta banyak pasokan peyek dan pengrajin tersebut tidak bisa memenuhi, maka mereka akan mendahulukan pengrajin tingkat bawah / kecil untuk memenuhinya dengan syarat sesuai standar. Sehingga setiap pengrajin mempunyai kesempatan untuk berkembang.

\section{Manfaat PKPEK bagi Pengrajin Peyek}

Belajar dari kegiatan tersebut yang bertujuan untuk pemberdayaan masyarakat, tentunya menjadi pertanyaan besar, bagaimana keseimbangan antara biaya yang dikeluarkan oleh NGO dan manfaat yang diperoleh. Ukuran manfaat apabila dibandingkan dengan investasi yang sudah dikeluarkan untuk pengadaan program tersebut bukan hanya diukur secara ekonomi melainkan dampakdampak pada aspek lain. Adapun manfaat dari program pemberdayaan yang dilakukan oleh PKPEK bagi masyarakat terutama dari aspek ekonomi.

Secara ekonomi, rata-rata program pemberdayaan masyarakat tersebut mampu meningkatkan pendapatan masyarakat terutama para pengrajin peyek bahkan masyarakat diluar sasaran kegiatan. Filosofinya sederhana, bahwa persoalan masyarakat miskin apalagi setelah terjadinya gempa terutama tidak mempunyai modal untuk berusaha. Melalui intervensi dari pendamping, maka memungkinkan mereka untuk memobilisasi tabungan yang digunakan untuk usaha. Modal yang terkumpul ditingkat kelompok, mengundang partisipasi dana yang lebih besar dari pihak yang ketiga.

Bahkan saat inipun masyarakat bisa membuat proposal sendiri yang ditujukan ke Founding melaluin pengawasan dari PKPEK. Realitasnya modal merupakan salah satu faktor terpenting dalam melakukan proses produksi. Artinya secara signifikan 
terbukti bahwa semakin besar modal yang digunakan maka semain besar output yang dihasilkan. Sehingga tentu saja terjadi peningkatan terutama yang terlihat untuk pembangunan rumah. Jika dikaitkan waktu setelah gempa hampir semua rumah yang disana rata dengan tanah. Ditambah lagi ketika mereka diberi dana rekonstruski untuk biaya rumah malah dipergunakan untuk mengembangkan usaha mereka. Mereka lebih memilih tidur ditenda atau rumah yang terbuat dari kayu. Pembangunan rumah mereka saat ini disebabkan terjadi peningkatan pedapatan masyarakat terutama dari pembuatan peyek.

Peran PKPEK manfaatnya sangat terasa dalam melakukan pemberdayaan terutama bagi pengrajin peyek sehingga masyarakat bisa menikmati hasilnya. Dari hasil produksi yang dilakukan saat ini saja, perhari bisa dikatakan total produksi 25 ribu bungkus / hari. Dengan bahan baku proyek sangat besar yaitu :

- beras (2 ton /hari)

- kacang 2 kelompok (4-5 ton/hari)

- minyak goreng (1500-2000 kg/hari)

Hal ini jika dibandingkan diawal pengembangannya hanya sekitar 1 kwintal kacang/hari. Omset yang dulu sekitar Rp.2.000.000,- sekarang mencapai Rp.120.000.000,-

Usaha produktif yang dilakukan oleh kelompok rumah tangga tersebut juga telah membuka kesempatan kerja atau usaha bagi kelompok itu sendiri maupun masyarakat luas. Seperti, kegiatan ini bida menyerap tenaga kerja dan tentu saja menambah pendapatan mereka. Untuk sekarang tenaga kerjanya terdiri dari 180 orang bekerja untuk memasarkan produk ini dan 400 orang untuk menggoreng dan membungkus.
Sedangkan untuk masalah pemasarannya cukup mencengangkan untuk daerah luar Jawa konsisten Bali baru-baru telah merambah Jakarta dan Palembang. Sedangkan untuk Jawa Tengah sudah $80 \%$, yaitu Solo, Wonogiri, Magelang, Brebes, Indramayu yang belum masuk sampai sekarang daerah Pantura.

\section{KESIMPULAN DAN SARAN}

Berdasarkan pertanyaan diatas dapat diambil beberapa kesimpulan yaitu :

1. Keberadaan PKPEK sebagai salah satu NGO yang bertujuan untuk memberdayakan masyarakat untuk meningkatkan pendapatan masyarakat, diawali dengan melakukan perubahan yang berhubungan dengan ekonomi kerakyatan. Perubahan tersebut dilihat dari aspek perubahan entitas usaha, dengan memberikan sarana dan prasarana yang dibutuhkan masyarakat antara lain aset, tenaga kerja serta motivasi usaha dari pelaku.

2. Adapun hambatan yang dihadapi oleh PKPEK selama proses pendampingan antara lain : a ) modal terutama bahan baku, terdapat beberapa bahan baku yang didatangkan dari daerah luar Yogyakarta, b) sarana produksi artinya tempat usaha yang hampir semua rata dengan tanah akibat gempa, c) pasar juga merupakan salah satu kendala utama mandegnya kegiatan pemberdayaan, hal ini disebabkan ada 3 pasar yang mengalami kerusakan cukup serius, akibatnya pengrajin susah 
mendapatkan bahan baku dan memasarkan usaha mereka, d) harga.

\section{UCAPAN TERIMAKASIH}

Penelitian ini terselenggara atas bantuan dari Yayasan PGRI Padang dan Pemda Bantul yang telah memberikan data dalam pelaksanaan penelitian.

\section{DAFTAR PUSTAKA}

Basuki, Alif dan Yanu Endar Prasetyo. (2007). Satu Langkah Bersama Untuk : Me-musiumkan Kemiskinan. Surakarta dan The Asia Foundation. Surakarta.

Clark, John. (199). NGO dan Pembangunan Demokrasi. PT. Tiara Wacana Yogya. Yogyakarta.

Ritzer, George dan Douglas J. Godman. 2007. Teori Sosiologi Modern Edisi 6. PT. Kencana Prenada Media Group. Jakarta.

Suyatno, Suparjan Hempri. (2003) Pengembangan Masyarakat dari Pembangunan sampai Pemberdayaan. Aditya Media. Yogyakarta.

Sunartingsih, Agnes. (2004) Pemberdayaan Masyarakat Desa Melalui Institusi Lokal. Universitas Gadjah Mada. Yogyakarta.

Suharto, Edi. (200). Membangun Masyarakat Memberdayakan Rakyat : Kajian Strategis Pembangunan Kesejaheteraan Sosial dan Pekerjaan Sosial. PT.Refika Aditama. Bandung.

Zarida. (2000). Pemberdayaan Terhadap Wanita Pedagang Kecil Di Pasar Tradisional Bandung. Puslitbang Ekonomi dan
Pembangunan Lembaga Ilmu Pengetahuan Indonesia. Jakarta.

(http://gis.deptan.go.id/website/sipetin/k abupaten/BANTUL5.htm) 